\title{
Acute Confusional State Caused by Tipepidine Hibenzate Intoxication in an Elderly: Caution About Suspended Solution
}

\author{
Satoshi Murao ${ }^{\mathrm{a}, \mathrm{c}}$, Hiromi Watanabe ${ }^{\mathrm{b}}$
}

\begin{abstract}
Tipepidine hibenzate is a non-opioid, centrally acting cough suppressant. Although overdose can cause altered mental status and other neurological symptoms, there have been no reports of tipepidine intoxication in an adult. We report a case of an elderly woman who presented with an acute confusional state and choreiform movements of her lower extremities due to tipepidine hibenzate intoxication. Over-ingestion of a thick precipitate of suspended tipepidine syrup possibly caused the acute intoxication in this case. It is important to recognize that tipepidine can cause acute intoxication and central nervous system symptoms, and unintentional overdosage could occur when prescribing the suspended syrup of the drug.
\end{abstract}

Keywords: Tipepidine; Intoxication; Suspended syrup; Altered mental status; Delirium; Involuntary movement

\section{Introduction}

Tipepidine hibenzate is a centrally acting cough suppressant in the non-opioid family. It has been prescribed mainly in Japan and other Asian countries since 1959. As it acts on the central nervous system, overdose can cause altered mental status and other neurological symptoms; however, there have been few reports of tipepidine intoxication, including six cases [1] in children and no cases in adults. We report a

Manuscript accepted for publication October 18, 2013

a Department of Diabetes and Endocrinology, Takamatsu Hospital, 4-18 Tenjin-mae, Takamatsu, Kagawa, 760-0018, Japan

${ }^{\mathrm{b}}$ Department of Internal Medicine, Takamatsu Hospital, 4-18

Tenjin-mae, Takamatsu, Kagawa, 760-0018, Japan

${ }^{\mathrm{c} C o r r e s p o n d i n g ~ a u t h o r: ~ S a t o s h i ~ M u r a o, ~ D e p a r t m e n t ~ o f ~ D i a b e t e s ~ a n d ~}$

Endocrinology, Takamatsu Hospital, 4-18 Tenjin-mae, Takamatsu,

Kagawa, 760-0018, Japan. Email: sat.murao@gmail.com

doi: http://dx.doi.org/10.4021/jmc1564w case of an elderly woman who presented with acute confusional state and choreiform movements of the lower extremities due to tipepidine hibenzate intoxication. Over-ingestion of thick precipitate of suspended tipepidine syrup possibly caused acute intoxication in this case.

\section{Case Report}

A 75-year-old woman was referred to our hospital for altered mental status, dysarthria, and choreiform movements of the lower extremities. On arrival, systolic blood pressure was $134 \mathrm{mmHg}$, diastolic blood pressure was $72 \mathrm{mmHg}$, heart rate was 107 beats per minute, and body temperature was $35.9^{\circ} \mathrm{C}$. The pupils were equal and not dilated. Meningeal sign was not observed. Laboratory results demonstrated a normal complete blood cell count (white blood cell count $7,920 / \mu \mathrm{L}$, red blood cell count $416 \times 10^{4} / \mu \mathrm{L}$, hemoglobin $11.9 \mathrm{~g} / \mathrm{dL}$, and platelet count $26.8 \times 10^{4} / \mu \mathrm{L}$ ), and blood glucose was $106 \mathrm{mg} / \mathrm{dL}$. Analysis of arterial blood gas was also normal ( $\mathrm{pH} 7.480, \mathrm{PCO}_{2} 40.1$ Torr, $\mathrm{PO}_{2}$ 80.6 Torr, $\mathrm{HCO}^{3-}$ $29.6 \mathrm{mmol} / \mathrm{L}$, and base excess $5.6 \mathrm{mmol} / \mathrm{L})$. Other laboratory tests, including hepatic and renal function tests and serum electrolytes, were within normal limits. Brain magnetic resonance imaging was also normal.

She had a history of mucosa-associated lymphoid tissue malignant lymphoma of the lung, which developed at age 67. It was in complete remission, but was complicated by chronic cough from radiation pneumonitis. She had been prescribed syrup with $83 \mathrm{mg}$ /day of tipepidine hibenzate 6 days prior to admission. Prescription dosage was within the recommended adult dosage of $60-120 \mathrm{mg} /$ day. Detailed history from her family revealed that she might have been taking this medicine more than twice the indicated dosage, accumulated in the lower part of the bottle.

As her confusional state and involuntary movements of lower extremities continued, $10 \mathrm{mg}$ of benzodiazepine was administered intramusculary. After $12 \mathrm{~h}$ of intravenous fluid administration, her mental status recovered to being alert and the involuntary movements disappeared, but she developed retrograde amnesia. Serum tipepidine hibenzate level on admission was $940.9 \mathrm{ng} / \mathrm{mL}$, which was about 25 times the 
maximum concentration after $40 \mathrm{mg}$ of tipepidine hibenzate ingestion. It decreased to $36.4 \mathrm{ng} / \mathrm{mL}$ after $36 \mathrm{~h}$.

\section{Discussion}

Determining the cause of altered mental status is often challenging. Drug intoxication is one important cause that must be considered.

While dependence and abuse of centrally acting antitussive agents has been well known [2], the acute adverse neurological effects of these medications, including tipepidine hibenzate, remain relatively unknown. Imai et al summarized six pediatric cases of acute tipepidine hibenzate intoxication, all of which presented with delirium [1]. In adults, Cuomo reported a 21-year-old woman who developed convulsions after a therapeutic dose of tipepidine ingestion [3]. To date, however, no cases of acute intoxication in adults have been reported.

Tipepidine hibenzate suppresses the cough reflex by acting on the cough center in the medulla, but the mechanism of its neurological side effects is unclear. It has been suggested that tipepidine inhibits the $\mathrm{G}$ protein-coupled inwardly-rectifying potassium (GIRK) channel [4]. GIRK channels hyperpolarize neurons in response to activation of $\mathrm{G}$ protein-coupled receptors and play an important role in regulating neuronal excitability and synaptic transmission [5]. Increased neuronal excitability by GIRK channel inhibition has been speculated to be one of the causes of convulsions and other neurological side effects in overdose of antidepressants [6]. In the present case, tipepidine might have caused the acute confusional state and involuntary movements via inhibition of GIRK channels, leading to increased excitability of the central nervous system.

The serum tipepidine hibenzate level on admission was markedly elevated. Tipepidine is metabolized mainly by the liver, but this patient's hepatic and renal functions were both normal. In general, it is easier to lose track of the dosage of syrup than tablets. Although it is likely that this patient took about twice the indicated dose, this still does not explain the severely elevated serum tipepidine concentration. Tipepidine hibenzate was prescribed in the form of suspended syrup. As tipepidine syrup is suspended in solution, sediment could have formed at the bottom of the bottle. Tipepidine syrup has been reported to form sediment easily when mixed with other drugs [1], but this may also occur with tipepidine syrup alone. Ingestion of excessive amounts of thickened syrup with sediment might explain why this patient became acutely intoxicated.

In conclusion, tipepidine hibenzate, a commonly prescribed antitussive drug in Asia, can cause acute intoxication accompanied by neurological symptoms not only in children but also in adults. When prescribing the suspended syrup form of drug, it is important to educate the patient not to ingest excess amounts or take sediments of the syrup, by agitating the bottle before ingestion.

\section{Disclosure}

The authors affirm that there are no potential conflicts (financial, professional, or personal) and that no company has provided any financial arrangement for this study.

\section{References}

1. Imai Y, Ishii W, Endo A, Arakawa C, Kohira R, Fujita Y, Fuchigami T, et al. Tipepidine hibenzate intoxication. Pediatr Int. 2011;53(5):779-781.

2. Murao S, Manabe H, Yamashita T, Sekikawa T. Intoxication with over-the-counter antitussive medication containing dihydrocodeine and chlorpheniramine causes generalized convulsion and mixed acidosis. Intern Med. 2008;47(11):1013-1015.

3. Cuomo RM. On the possible convulsive activity of an antitussive piperidinic derivative ('tipepidina ibenzato') in man. Acta Neurol (Napoli). 1982;4(2):110-116.

4. Kawaura K, Miki R, Urashima Y, Kawahara R, Soeda F, Shirasaki T, Takahama K. Pharmacological mechanisms of antidepressant-like effect of tipepidine in the forced swimming test. Behav Brain Res. 2012;226(2):381-385.

5. Luscher C, Slesinger PA. Emerging roles for G proteingated inwardly rectifying potassium (GIRK) channels in health and disease. Nat Rev Neurosci. 2010;11(5):301315 .

6. Kobayashi T, Washiyama K, Ikeda K. Inhibition of $\mathrm{G}$ protein-activated inwardly rectifying $\mathrm{K}+$ channels by different classes of antidepressants. PLoS One. 2011;6(12):e28208. 